\title{
Effects of feed intensity and breed on postpartum blood metabolites
}

\author{
Theodoros Ntallaris ${ }^{1 *}$, Patrice Humblot ${ }^{1}$, Ylva Sjunnesson ${ }^{1}$, Renée Båge ${ }^{1}$, Joëlle Dupont ${ }^{2}$, Britt Berglund ${ }^{3}$ \\ From Animal Obesity - causes, consequences and comparative aspects \\ Uppsala, Sweden. 14-16 June 2015
}

\section{Introduction}

In dairy cows, postpartum negative energy balance impairs fertility.

\section{Objective}

The aim of this study was to investigate the influence of high and low feed intensity starting one month before first calving on blood metabolites of energy balance in Holstein $(\mathrm{H}, \mathrm{n}=14)$ and Swedish Red dairy breed (SRB, $\mathrm{n}=14$ ) kept in a loose housing system.

\section{Material and methods}

The control group $(\mathrm{C}, \mathrm{n}=12)$ was fed a diet targeting high production $(35 \mathrm{~kg} /$ day Energy-Corrected Milk, $\mathrm{ECM})$. The lower feeding intensity $(\mathrm{L}, \mathrm{n}=12)$ was achieved by giving $-50 \%$ concentrate to target $25 \mathrm{~kg} /$ day ECM. Blood was sampled every 2 weeks until 2 months postpartum and then once a month until Day 120 . Plasma was kept frozen until analysis for glucose, insulin and non-esterified fatty acids (NEFA) concentrations. Data were analyzed with Mixed linear models.

\section{Results}

For glucose, effects of breed $(\mathrm{p}<0.01)$ and time $(p=0.01)$ were observed. Postpartum glucose levels were constantly higher in SRB when compared to $\mathrm{H}$ cows $(56.7 \pm 1.9$ vs $49.9 \pm 2.0 \mathrm{mg} / \mathrm{dl})$. For insulin, there was an interaction between diet and time $(\mathrm{p}<0.03)$; concentrations being higher in $\mathrm{C}$ than in the $\mathrm{L}$ group until 3 months and not different later. For NEFA's an effect of time was observed $(\mathrm{p}=0.001)$ and a tendency $(\mathrm{p}<0.10)$ for interaction between breed and diet. Holstein

\footnotetext{
* Correspondence: theodoros.ntallaris@slu.se

${ }^{1}$ Department of Clinical Sciences, Swedish University of Agricultural Sciences, Uppsala, Sweden

Full list of author information is available at the end of the article
}

tended to have lower NEFA concentrations with the low diet whereas the inverse was observed for SRB.

\section{Concusion}

These results indicate that feed intensity and breed influence energy mobilization. However, no relationships were found with reproductive variables.

\section{Funding}

The study was financed by "PROLIFIC" EU grant No311776.

\section{Authors' details}

${ }^{1}$ Department of Clinical Sciences, Swedish University of Agricultural Sciences, Uppsala, Sweden. ${ }^{2}$ INRA PRC, Tours, France. ${ }^{3}$ Department of Animal Breeding and Genetics, Swedish University of Agricultural Sciences, Uppsala, Sweden.

Published: 25 September 2015

doi:10.1186/1751-0147-57-S1-012

Cite this article as: Ntallaris et al:: Effects of feed intensity and breed on postpartum blood metabolites. Acta Veterinaria Scandinavica 2015 57(Suppl 1):012.

Submit your next manuscript to BioMed Central and take full advantage of:

- Convenient online submission

- Thorough peer review

- No space constraints or color figure charges

- Immediate publication on acceptance

- Inclusion in PubMed, CAS, Scopus and Google Scholar

- Research which is freely available for redistribution 